\title{
Form and Theme in Merindu Kampus: A Reflection Note About Pandemic Covid-19 by Indonesian Language and Literature Students
}

\author{
Parmin ${ }^{1, *}$ Tengsoe Tjahjono ${ }^{1}$ Heny Subandiyah ${ }^{1}$ Ririe Rengganis ${ }^{1}$ \\ ${ }^{1}$ Faculty of Languages and Arts, Universitas Negeri Surabaya, Indonesia \\ *Corresponding author. Email: parmin@unesa.ac.id
}

\begin{abstract}
The covid-19 pandemic has hit the world, including Indonesia. The Indonesian goverment has therefore issued policies including large-scale of social restrictions (PSBB). Several institutions issued policies, including Universitas Negeri Surabaya (UNESA). UNESA has been implementing online learning since mid-March 2020. All of students are studying from home. The effect of studying from home triggers students to create a collection of writings which were later recorded under the title Merindu Kampus: Reflection Notes. This book contains a reflection on the covid-19 pandemic written by students of the Indonesian Language and Literature Department (JBSI). This book is interesting to research. The purpose of this paper is to describe the form of reflection notes and the theme of JBSI students' reflection notes. This paper used an objective approach, descriptive type. The data source for this paper is the book title Merindu Kampus: Notes on Reflection. The data of this research are sentences, paragraphs, and discourses contained in the data source. The results of the research were, first, in general showed that the most of students' writing is in the form of reflective notes, a form that is considered the most suitable for conveying the hearts of students regarding the Covid-19 pandemic. Second, the themes conveyed by students in general are in the form of surprise, disappointment, and fear accompanied by prayers and hopes that Covid-19 will end soon and students can return to campus.
\end{abstract}

Keywords: Reflection Notes, University Students, Pandemic, Poem, Story, Letter.

\section{INTRODUCTION}

Covid-19 is spreading around the world. China is listed as the first country to report Covid-19 cases. China reported the presence of this new disease on December 31, 2019. Over time, the first cases of Covid-19 outside China were reported in Thailand. Then spread to the Middle East. France became the first country on the European continent. Then, it continous to the Continent of Australia, Egypt and Algeria.

The first death toll from Covid-19 occurred in China, then the Philippines, the US, then spread to Spain and Italy. The spread of the Covid-19 virus continues in several countries and for the time being no cure has been found, consequently, many steps are beginning to prevent it. One of them is with restrictions, efforts to reduce

human contact until lockdown or quarantine. Seeing the rate of spread of the Covid-19 virus around the world,
WHO has set the Covid-19 outbreak or the corona virus (SARS CoV-2) to be a global pandemic.

With this pandemic status, WHO asks all countries to increase their emergency response to Covid-19. In Indonesia, for the handling of Covid-19, one of the government policies is the implementation of large-scale social restrictions (PSBB). The government issued a PSBB policy in handling Covid-19 by issuing PP Number 21 of 2020 and Presidential Decree Number 11 of 2020. Several regions have implemented PSBB in their regions by limiting various community activities. Starting from school, work, and worship which is done at home and prohibits people from gathering.

Government policies are followed by policies in each region. These policies are also taken by other institutions, in this case educational institutions. UNESA as an educational institution through the chancellor issued a circular regarding the Covid-19 pandemic. Chancellor's Circular Number: B / 15254 / UN38 / TU.00.02 / 2020 
concerning Prevention Measures for the Spread of Corona Virus Desiase-19 (Covid-19) in UNESA. One of its contents is to regulate that theoretical lectures are carried out by E-Learning, Vi-Learning, Mailing List, WA Group, Line, Skype, or others platforms. While practical lectures are carried out in the form of giving other relevant assignments according to learning achievement. The policies were followed by the suggestion of students to return home and start doing many things from home. Students who are at home for a long time will certainly bring up complaints, soliloquies, reflections, and various feelings in written form.

One of the students' work in expressing their feeling is Merindu Kampus. It is a book which consists of reflection notes by JBSI students. The writings collected in this book are interesting to study. This book is a reaction to the events experienced by students, namely the Covid-19 pandemic. Every individual actually often doing an reflection in his daily life. However, some of them did not realize. Hence, doing a reflection could maintain many benefits, one of them is that future actions will be better. Reflection is an ongoing activity. Reflection is carried out intensively. In a simple sense, reflection is looking back. What can be reflected is something that has happened and has been experienced. The reflective notes of this paper refers to the notes written by students when they experience or undergo an event or daily life, which they contemplate (the process of appreciation). It is written as a form of introspection or (to do) other things that are more positive.

The objectives of this paper are a) to describe the form of reflective notes about the covid-19 pandemic by JBSI FBS UNESA students; and b) describe the theme of the reflection notes on covid-19 by JBSI FBS UNESA students.

\subsection{The Form of Refection Notes}

Reflection comes from Latin which means "to bend or to turn back". In the world of education, reflection is defined as a process of rethinking so that it can be interpreted or analyzed. Reflection is a term that is known in everyday life. Another understanding, reflection is a process of looking back to back. Reflection, especially in the form of experience, can produce changes and actions and even reconstruct learning. Reflection (or reflection notes) is a reaction to an event that a person experiences, to contemplate, then learn the lessons behind the event. Reflection notes that would be anaylized are in the form of poetry, letters, stories, reports, and reflection notes.

\subsubsection{Write the reflection in the form of Poetry}

"Poetry is an expression of thought and feeling that is solid and rhythmic. It can be in the form of lines and verses using beautiful language in aesthetic corridors [1]. Poetry is a process that many people experience. It is because in the beginning of each word was poetry. Thus, each individual has a different experience in writing poetry. Experience, physical mind and spiritual mind, become the initial capital for someone who will write poetry. Settling into the experience is the next step that needs to be maintained and cared for. As stated by Jabrohim, et al. [2] that the poet will never underestimate his experience. Maulana [3] said that the motivation to write poetry came from a totally internalized experience. This deposition process requires a variety of time for each person. After this depositional process, then it is born (written down). Writing into poetry is the main step. The ability to choose and finally determine the correct diction and represent deposits is a stage that is not easy. Choosing diction is the experience of reading and exploring the poetry of predecessor poets.

In this regard, writing a poetry emphasizes the willingness to "dare to try and have good faith". What is needed is to explore as many topics as possible, then develop into poetry. Writing poetry is freely divided into three, namely 1) writing poetry that contains your own ideas, 2) presenting an interesting choice of words and rhymes, and 3 ) writing poetry creatively.

(1) Writing poetry that contains their own ideas means that everyone has ideas or ideas, but not everyone expresses them in poetic form. Why is that? The answer can be various. But of all the answers, the main problem is not having the courage to try to write it in poetic form. Courage to try is the answer to the difficulty of writing poetry.

(2) Displaying an interesting choice of words and rhymes means that the right choice of words is words that can represent the expression of the author. In other words, the writer chooses words according to the expression of his feelings. When the word represents the author's expression, the word is correct.

(3) Writing poetry creatively, meaning that writing poetry can be done in various ways and tips. The explanations below are some tips on writing poetry. Every tip does not always acceptable for someone.

However, there are at least 16 tips for writing poetry. The sixteen tips are: 1) writing by parsing one's own name; 2) writing based on char $n$ sensory stimulation; 7) writing based on the experiences of friends; 8) rewrite existing poetry; 9) writing for praying to God; 10) writing an invitation to do something; 11) writing for lovers; 12) 
writing to tell a story (event or character); 13) write to powerful leaders; 14) write on the response to music that is heard; 15) writing through existing poetry patterns; and 16) writing on human sensory responses.

The idea of writing poetry above can still be developed. The ideas above are not necessarily applicable and easily implemented by everyone. The ideas above still need clearer and more concrete stages. Every poet has a different experience and way of writing.

\subsubsection{Writing Reflections in Letter Form}

Soedjito [4] said the letter was a means of written communication to convey information to other parties. There are three important requirements related to this, namely the form, content and language of the letter [4]. A letter is a means of communication to convey written information by one party to another with the aim of informing the intent of the message from the sender. The function of the letter covers five things: means of notification, requests, thoughts and ideas; written evidence; reminder; historical evidence; and work guidelines.

Letters are generally classified into three categories, namely personal letters, official letters, and commercial letters when viewed in terms of form, content and language. Meanwhile, if classified based on usage, it can be divided into three, namely personal letters, official letters, and official letters.

Writing a letter is conveying meaning to another person, the intended person. This other person is a reader. The process is certainly not too different from conveying ideas in other forms of work, such as poetry. There are things to be conveyed, need the media, choose diction, and write it down

\subsubsection{Writing Reflections in Story Form}

A story is a series of events that are conveyed, whether they come from real events (non-fiction) or not real (fiction). Writing a story is like writing any other process. Ideas to be written can arise from personal experiences, other people, or reading books, watching movies or television shows, and others. Ideas become the starting material, enter into a person, are digested, and so on. Then start to the next stage, the writing process. The writing process is different for everyone. Some wrote it immediately, reread it, revised it, and finished it. This kind of experience is also commonly found in writers in Indonesia. Some are in the process through a creative writing workshop. There are those who proceed through education, to become graduates of Indonesian language or Indonesian literature. There are various ways a person can proceed to become a good story writer. Ariadinata [5] said that writing a good story absolutely requires two elements, namely the ability to master techniques and know what to write.

There are many ways to write a story. Everyone also has ways or tips in writing stories that do not need to be forced to be the same as others. Writing stories is an individual experience. If you read other people's tips for writing stories, this can be used as a comparison. One of the steps to writing a story is a) choosing a story topic, b) starting writing, c) chaining events, d) building conflict, e) ending the story, and f) editing.

\subsubsection{Writing Reflections in Reportage Form}

Reportage means news or reporting. From the word "report" which means "to report" or "to preach". In a journalistic context, reporting is the process of collecting data to compile news. Reporting can be said to be the most important journalistic process because from this process material or information is collected to be reported.

Reporting is the process of collecting data and facts of an event as material for writing or presenting news in the mass media. There are three reporting techniques, namely 1) observation, 2) interviews, and 3) data research. Reporting is part of the news processing process, namely the second stage (news hunting, news gathering). The news creation process usually starts from an editorial meeting. Fry (in [6]) the reportage writing system follows the steps of compiling ideas, reporting, organizing (planning and sequence), conceptualizing (draft), and improving.

\subsubsection{Writing Reflections in the Form of Reflection Notes}

Writing reflections is actually like writing a diary. The difference is like the meaning of the word, reflection or reflection, what is written will reflect something, both to yourself and to others. Reflection can be said to be like a mirror to someone. Therefore, when a person looks in the mirror, he can see himself. Reflection can sometimes make a person understand much more about themselves and others so that they are grateful to have a life that is complete with weaknesses and strengths. Reflection is the present that looks at the past to be better in the future.

The more often you write reflections, the more someone will discover God's ways and His message for humans. Reflecting writing is pouring what is experienced and felt in writing. It is no need to be 
aggravated by the explanation that what is written is heavy and requires reflection. Reflection writing is writing notes on experiences that have been deposited, pondered over, lived in (which are then given the choice of an attitude of optimism, confidence, empathy for what has happened) and it is hoped that the writing will benefit himself and others who read it.

\subsection{The Themes (content) of Reflection Notes}

Something that exists certainly has two things, namely form and theme (content). In KBBI (Indonesian dictionnary) online, content means; 1) something that is (contained, contained, etc.) in an object and so on; 2) what is written in it (about books, letters, etc.); 3) the core or main part of a discourse (speeches, talks, etc.). Themes are the main ideas in writing an article. Themes are an important element in writing. Themes are the basis on which a writer will develop. The existence of an important theme for a writer. That is, an article is not born without a clear theme. The theme is there first, then the writer explores the theme in various ways. The author will make observations, observations, or read some literature to enrich the theme before being born into a writing. In this case, the content and the theme are the same thing.

Writing themes can come from themselves or from outside. From yourself can be the experience of the author. From the outside, the theme can come from other people's experiences or reading books, and so on. Writing themes are very diverse, ranging from things related to oneself, things that are around, or things that are big and outside. It can also be distinguished from small themes, medium themes, to large themes. Themes about daily habits, such as eating-drinking-sleeping at home are minor themes, but if done with extraordinary research and involving people from different ethnicities and different countries, then the theme can become big. The type of writing theme varies, depending on which point of view.

\section{METHODS}

\subsection{Approach and Type of the Research}

The approach used in this paper (research article) is an objective approach. This research article is a descriptive type, which describes the writings / works of JBSI students in the form of reflective notes. What is described is the form and content.

\subsection{The Source of the Data}

The source of this research articles is the book Merindu Kampus: Notes on Reflection. The book is a reflection note written by JBSI students. The complete students' data shows in Table 1 .

Table 1. Students Information

\begin{tabular}{|l|l|l|}
\hline No. & Major/Year/Class & $\begin{array}{l}\text { Students } \\
\text { amounts }\end{array}$ \\
\hline 1 & $\begin{array}{l}\text { Indonesian language and } \\
\text { literature education /2019/C }\end{array}$ & 41 \\
\hline 2 & $\begin{array}{l}\text { Indonesian language and } \\
\text { literature education /2018/B }\end{array}$ & 44 \\
\hline 3 & Indonesian Literature/2017 & 37 \\
\hline Total & & 122 \\
\hline
\end{tabular}

This writing data is in the form of sentences, paragraphs, and discourses contained in the data source.

\subsection{Data Technique}

The data collection technique in this paper is the reading note technique (batat). Batat technique is carried out in the following stages: a) careful reading of data sources, b) marking data found, c) grouping or classifying data according to the purpose of this paper

\subsection{Data Analysis}

The data analysis technique in this paper is descriptive-analytical. That is, the written data obtained (collected) in the form of reflection notes were analyzed descriptively.

\section{RESULTS AND DISCUSSION}

\subsection{The Forms of Reflection Notes}

The form of writing reflective notes produced by these students is in the form of poetry, letters, stories, reports, and reflection notes. This book is in the form of a reflective note about the covid-19 pandemic of JBSI FBS students, UNESA. The students in question are JBSI students' in the year 2017, 2018, and 2019. Each year has been chosen one class serves as a representative (sample).

Table 2 below is a table of JBSI students' reflective notes on the COVID-19 pandemic, presented consecutively starting in year 2019, 2018 and 2017. 
Table 2. Students' Major and Students' form of reflection notes about Pandemic Covid-19

\begin{tabular}{|c|l|c|c|c|c|c|l|}
\hline \multirow{2}{*}{ No. } & \multirow{2}{*}{ Major } & \multicolumn{5}{|c|}{ Form of work } & \multirow{2}{*}{ Note } \\
\cline { 3 - 7 } & & $\mathrm{P}$ & $\mathrm{L}$ & $\mathrm{S}$ & $\mathrm{R}$ & $\mathrm{RN}$ & \\
\hline 1 & $\begin{array}{l}\text { PBSI/20 } \\
19, \mathrm{C} \\
\text { Class }\end{array}$ & 19 & 7 & 6 & 0 & 9 & $\begin{array}{l}41 \\
\text { reflection } \\
\text { note }\end{array}$ \\
\hline 2 & $\begin{array}{l}\text { PBSI/20 } \\
18, \mathrm{~B} \\
\text { Class }\end{array}$ & 12 & 6 & 7 & 0 & 19 & $\begin{array}{l}44 \\
\text { reflection } \\
\text { note }\end{array}$ \\
\hline 3 & $\begin{array}{l}\text { IL, year } \\
2017\end{array}$ & 7 & 0 & 10 & 0 & 19 & $\begin{array}{l}36 \\
\text { reflection } \\
\text { note }\end{array}$ \\
\hline & Total & 38 & 13 & 23 & 0 & $\mathbf{4 7}$ & Total 121 \\
\hline
\end{tabular}

Explanation: PSBI: Indonesian language and literature education, IL: Indonesian Literature, $P$ : Poetry, L: Letter, S: Story, R: Reportage, RN: Reflection Notes

The number of PBSI students, year 2019 for C class are 41 students. All students wrote and submitted their works. The students' works of this class consisted of 19 in the form of poetry, 9 in the form of reflective notes, 7 in the form of letters, and 6 in the form of stories. There are no students who write in reportage form.

The number of PBSI students, year 2018 for B class are 44 students. All students wrote and submitted their works. From 44 students, their works consisted of 19 were written in the form of reflective notes, 12 were written in the form of poetry, 7 were written in the form of stories, and 6 were written in the form of stories. There were no students who wrote in reportage form.

The number of students in the year 2017, which Indonesian Literature study program are 37 students. One student did not send a reflection note, so the final results were 36 posts. The dominant form of writing in this class were 19 reflective notes, 10 letters, and 7 poetry notes. There were no students who wrote in reportage form.

Overall the number of students who sent writings was 121 students, with the composition of the written form were 38 in the form of poetry, 13 in the form of letters, 23 in the form of stories, 0 in the form of reportage, and 47 in the form of reflective notes. In general, the most common form is reflective notes, a form that is considered the most appropriate to convey the hearts of students regarding the Covid-19 pandemic.

\subsection{The Themes (Content) of Reflection notes}

All the writings in the book Merindu Kampus: Reflection Notes have the same theme, namely about the Covid-19 pandemic. Based on this theme (main theme), students develop a writing. There were various responses from the main theme on which the writing was based. Therefore, to make it easier to classify the main theme (content), it is necessary to derive subordinate themes on the basis of the writer (student) 's perspective and attitude towards the main theme, namely the Covid-19 pandemic. For this reason in this case, the main theme regarding the Covid-19 pandemic is lowered into five groups, namely a) surprise, disappointment, and fear which ends with prayers and hopes; b) mediocrity which ends in prayer and hope; c) accept what happens which ends in prayer and hope; and e) describe or other content that does not end with prayers and hopes. The division (grouping) was also due to the number of writings in the book Merindu Kampus: Reflection Notes very much, namely 121 pieces.

To show the diversity of the development of the main themes, a few examples are presented below.

Maybe it's time for repentance

It's already reprimanded by the Owner of the universe

Because life is only a flash

Come on everyone, let's life healthy

At home, you have to keep up the spirit

In order to stay strong and strong

Prayer always prays

May we all stay safe

Healthy and healthy.

(Hope sooner pass, Rosa Kurnia Widiawati, year 2019)

The conditions caused by this damn pandemic are very complicated, I am annoyed especially when the online college pandemic is still being enforced, it is actually okay to enforce it online, but please don't make your job as a livestock arena, tasks always appear with a blink of an eye, tasks are always in sequence like a coal train whose smoke is billowing, like my brain at this time, the task is always there never absent, the brain is forced to always work, one task has not yet been completed, another task appears. It's an irony, at other times we focus on the 
perfection of fasting, we are divided between focusing on fasting and focusing on the task at hand.

(A Greatest Hope, Nina Nur Alfi Aulia, year 2019)

I really miss studying with friends on campus, doing assignments together, reading books while lying down in the library, eating at the campus canteen, I really miss all activities on campus. Initially I liked it because it was a long holiday and was able to be at home, but it turned out that this holiday was too long because more and more people were infected with the Covid-19 virus so that people were advised not to go anywhere and not to move outside the home if it was not important or urgent.

(LDR with Campus because of Covid-19, Rise Anika Sasti, year 2018)

A Letter for Mbok and Pak Wek

For Mbok, Pak Wek.

Sorry for this year's Eid, my mother, father, brother, and I can't go home, can't accompany Mbok and Pak Wek at home. Actually we really wanted to visit Mbok and Pak Pek at home. However, because of the Covid-19 pandemic, we cannot accompany Eid Mbok and Pak Wek. I know how Mbok and Pak Wekfeel, it must be sad because Mbok and Pak Wek's two children can't go home. Pak Puh must be eager to go home to introduce his son who was just born. Yes, finally Mbok and Pak Wek had a grandson. Pak Puh is also not going home because of this pandemic, especially now that you have a baby you must be very careful. It must be happy if we can all gather when Eid arrives. For this year, I've actually scheduled Eid together with Mbok and Pak Wek.

(Riska Novi Hariyanti, year 2018)

\section{Sorrow of Our Land}

For the umpteenth time, Mother Nature was defeated by the situation

\section{Thousands of people feel helpless}

Against the unseen

Even the hero of the vanguard almost gave up

Others, always feel indifferent to what is going on

(Vira Yanuar Ramadhani, year 2017)

\section{Notes From Home}

The Covid-19 pandemic has been with all of us for months. There are many things that accompany it, from fear, panic buying, anxiety, boredom, and loss, both family members, work, and freedom. We are required to be at home only. We are required not to meet relatives, as proof of love. We are required to contribute to the country, by continuing to be at home. I often go to some social media, I see a lot of people, not all, saying they are bored at home, they are starting to go crazy, they are getting insane, they want to go out, they want to play. At that time I was sad, if I could swap their positions with my parents I would of course change them. My parents are both merchants. Every day I have to work, every day I have to meet and interact with many people, which I don't know is healthy or not. From there I understand that maybe we should start to be grateful and see from the perspective of others.

(Hana Ica Fadiah, year 2017)

It is true that the main theme of the Covid-19 pandemic has been addressed by various perspectives and attitudes by students. Therefore, the various perspectives and attitudes need to be grouped to make it easier to enter student writing (of course, into certain groups).Table 3 is a recapitulation of the contents of the reflective notes about the Covid-19 pandemic written by JBSI FBS Unesa students.

Table 3. Recapitulation the contents of the reflective notes

\begin{tabular}{|l|l|l|l|l|l|l|}
\hline \multirow{2}{*}{ No. } & \multirow{4}{*}{ Major } & \multicolumn{3}{|l|}{$\begin{array}{l}\text { Themes } \\
\text { (Content) } \\
\text { meaning }\end{array}$} & \multirow{2}{*}{ Information } \\
\cline { 3 - 6 } & & K & B & M & D & \\
\hline 1 & $\begin{array}{l}\text { PBSI, } \\
\text { year } \\
\text { 2019, } \\
\text { kelas C }\end{array}$ & $\mathbf{1 9}$ & $\mathbf{1}$ & $\mathbf{1 1}$ & $\mathbf{1 0}$ & $\begin{array}{l}\text { 41 reflection } \\
\text { notes }\end{array}$ \\
\hline 2 & $\begin{array}{l}\text { PBSI, } \\
\text { year } \\
\text { 2018, } \\
\text { kelas B }\end{array}$ & $\mathbf{2 7}$ & $\mathbf{1}$ & $\mathbf{8}$ & $\mathbf{8}$ & $\begin{array}{l}\text { 44 reflection } \\
\text { note }\end{array}$ \\
\hline 3 & $\begin{array}{l}\text { IL, year } \\
\text { 2017 }\end{array}$ & $\mathbf{9}$ & $\mathbf{3}$ & $\mathbf{4}$ & $\mathbf{2 0}$ & $\begin{array}{l}\text { 36 reflection } \\
\text { note }\end{array}$ \\
\hline \multicolumn{1}{|l|}{ Total } & $\mathbf{5 5}$ & $\mathbf{5}$ & $\mathbf{2 3}$ & $\mathbf{3 8}$ & \\
\hline
\end{tabular}

Explantion:

PSBI: Indonesian language and literature education, IL: Indonesian Literature, K: Surprise, disappointment, and fear which ends with prayer and hope, B: Just 
ordinary ones that end with prayers and hopes, M: Receiving what happened which ended in prayer and hope, D: Describing or other content that does not end with prayers and hopes

The main theme of student reflection notes is the Covid-19 pandemic that has hit the world, including Indonesia. Based on the data, the themes (content) conveyed by students in their reflective notes about the Covid-19 pandemic were divided into four groups. The first group, namely a) surprise and anger, ended with prayers and hopes, total are 55 pieces; b) mediocre, ended with prayers and hopes, there are 5 pieces; c) can receive, end prayers and hopes, total are 23 pieces; and d) describes or other contents that do not end with prayers and hopes, there are 38 pieces. Based on this data, in general the most themes (content) that were conveyed were surprise, disappointment and fear which ended with hope and prayer. The hope of the students is that the pandemic would end soon and they can return to campus soon.

\section{CONCLUSION}

Based on the results and discussion, it can be concluded as follows. First, the most form of reflection notes is in the form of reflection notes. The majority of writings are in the form of reflective notes, a form that is considered the most appropriate to convey the hearts of students regarding the Covid-19 pandemic. Second, the theme (content) presented is in the form of surprise, disappointment, and fear which ends with prayer and hope. The hope of students is that they can immediately return to campus and study as before the Covid-19 pandemic.

\section{REFERENCES}

[1] T. Tjahjono, Mendaki Gunung Puisi: Ke Arah Kegiatan Apresiasi. Malang: Bayumedia Publishing, 2010.

[2] Jabrohim, S.A. Sayuti, and C. Anwar, Cara Menulis Kreatif. Yogyakarta: Pustaka Pelajar, 2003.

[3] S.F. Maulana, Apresiasi dan Proses Kreatif Menulis Puisi. Edisi Revisi. Bandung: Penerbit Nuansa Cendekia, 2015

[4] Soedjito, Terampil Menulis Surat Resmi Bahasa Indonesia. Jakarta: Prestasi Pustakaraya, 2010.

[5] J Ariadinata, Aku Bisa Nulis Fiksi: Panduan Ringkas Jadi Penulis Hebat!. Yogyakarta: Diva Press, 2016.
[6] L. Ishwara, Catatan-Catatan Jurnalisme Dasar. Jakarta: Penerbit Buku Kompas, 2005. 